\title{
Effect of trans-Cinnamaldehyde and High Pressure Treatment on Physico-chemical and Microbial Properties of Milk during Storage Periods
}

\author{
Ji-Yeon Chun, Kwon-Beom Kim, Jong-Boo Shin, and Sang-Gi Min* \\ Department of Food Science and Biotechnology Animal Resources, Konkuk University, Seoul 143-701, Korea
}

\begin{abstract}
This study was carried out to investigate the effect of trans-cinnamaldehyde and high pressure treatment on milk. Cinnamon oil milk was manufactured by high speed homogenization (3,000 rpm) and high pressure homogenization (500 and 2,000 bar) processing UHT milk and trans-cinnamaldehyde of various concentrations $(0$ to $0.1 \%(\mathrm{w} / \mathrm{v}))$. Cinnamon oil milk was inoculated with Escherichia coli $(6.4 \mathrm{Log} \mathrm{CFU} / \mathrm{mL})$ and kept at $7^{\circ} \mathrm{C}$ for $10 \mathrm{~d}$ to observe the antibacterial effect. The cinnamon oil milk containing $0.05 \%$ (w/v) trans-cinnamaldehyde initially began to show an antibacterial effect and Escherichia coli completely died in cinnamon oil milk added $0.1 \%(\mathrm{w} / \mathrm{v})$ trans-cinnamaldehyde on the 6th day of storage. The result of the TBA value showed that the addition of $0.1 \%(\mathrm{w} / \mathrm{v})$ trans-cinnamaldehyde was also effective to protect lipid oxidation. In the physical properties of cinnamon oil milk, particle sizes were enlarged in all samples during storage periods and the total color difference of cinnamon oil milk was slightly increased as level of high pressure. The surface tension of cinnamon oil milk treated 2,000 bar was remarkably higher than other samples. It seems that trans-cinnamaldehyde showed antibacterial activity and antioxidation effect at 0.05 and $0.1 \%(\mathrm{w} / \mathrm{v})$ of concentration. Remarkably, high pressure treatment did not influence its microbial property but slightly affected the physical properties of cinnamon oil milk.
\end{abstract}

Key words: trans-cinnamaldehyde, high pressure homogenization, antibacterial activity, Escherichia coli, milk

\section{Introduction}

Food safety and hygiene are important issues in the food industry and food borne diseases have been major problems in both developed and developing countries. Therefore, drugs such as antibiotics have been used frequently, and over prescription of antibiotics has causes a continuous increase in the tolerances of the strains to which they are applied, causing an even greater potential threat to human health.

The over-prescription of antibiotics leads to a reduction of their effectiveness. Hence, it is necessary to find new antimicrobial agents for food hygiene. Essential oils from plants are attractive substances to consumers, because they are natural food stuffs. It has been reported that their antibacterial properties can help extend the shelf-life of food. Moreover, essential oils are important raw materials in the food, perfume, and the pharmaceutical industries. Molecular encapsulation of essential oils improves their

*Corresponding author: Sang-Gi Min, Department of Food Science and Biotechnology of Animal Resources, Konkuk University, Seoul 143-701, Korea. Tel: 82-2-450-3680, Fax: 82-2-455-1044, E-mail: minsg@konkuk.ac.kr chemical properties and thermal stability. However, essential oils are very sensitive to the affect of light, temperature, oxygen, and humidity (Amrita et al., 2009; Burt 2004; Cevallos et al., 2010; Hossain et al., 2011; Rahman et al., 2011; Yossa et al., 2010).

Trans-cinnamaldehyde (CIN, 3-phenyl-2-propenal) is organic compound that gives cinnamon flavor and odor, and accounts for the greater part (around 90\%) of cinnamon oil. It is pale yellow in color and forms a low viscous liquid. It has been widely known that the most common application of $\mathrm{CIN}$ is as a flavoring agent of foods such as gum, ice cream, candy, and beverages. CIN is increasing in importance as the most effective antibacterial and antioxidant essential oil, and has been used in beverages such as fruit juice, milk and so on. Some researchers have evaluated the antibacterial or antioxidant properties of spice extract, i.e. eugenol, gingerol, thyme, capsaicin, $\mathrm{CIN}$ and so on, and among them, CIN was ranked quite highly (Amrita et al., 2009; Hossain et al., 2008; Hossain et al., 2011). Many researchers have studied the antimicrobial effect of CIN. A research team at the University of Illinois found that CIN inhibits oral bacteria growth by $>50 \%$; therefore, it could reduce production of volatile compounds that cause bad smells. It is particularly effec- 
tive against bacteria living at the back of tongue, and reduces anaerobic bacteria populations by about $43 \%$. The combination of cinnamon and clove essential oil shows a synergistic antimicrobial effect, although the active concentration of the essential oil must be determined (Cevallos et al., 2010; Chun 2012; Goñi et al., 2009). CIN could be used to extend the stability of foods during storage.

Food producers continuously search for ways to improve color, taste, texture and nutritional value. Over the years, homogenization technology has evolved because consumers have demanded products with a longer shelflife and better stability. From the early 1980s new technology was introduced for fine emulsion, and is based on high pressure capacity (Cook and Lagace, 1985; Paquin, 1999). In recent years, high pressure homogenization (HPH) considered advanced production techniques of the food industries because it causes unique changes in the physico-chemical and functional properties of food materials, such as increasing encapsulation efficiency, bioavailability and physical stability, without causing excessive turbidity. Moreover, dairy products result in much finer lipid droplets through the application of HPH (Ciron et al., 2010; McClements and Qian, 2011; Van Hekken et al., 2007). Milk or milk-based products are typically heat treated to remove microorganisms and to prolong selflife. However, thermal processing could deteriorate some of the nutritional properties, and off-flavor and easily occurred protein denaturation (Bouaouina et al., 2006; Vassila et al., 2002). The stability of milk could be improved, and activation of bacteria inhibited without thermal processing, which causes changes in the nutritional and sensory properties (Smiddy et al., 2007; Wormbs et al., 2004).

In this study, cinnamon oil milk (CM) was manufactured by using high speed homogenizer and high pressure homogenizer with various concentrations of CIN and UHT milk. CM samples were inoculated with Escherichia coli ATCC 10536 which has been typical index of food quality in food industry in order to observe the antibacterial activity of CIN. CM samples were analyzed through microorganism observation, TBA value, particle size, $\mathrm{pH}$, total color difference, and surface tension, for a storage period of $10 \mathrm{~d}$ at $7^{\circ} \mathrm{C}$.

\section{Materials and Methods}

\section{Materials}

Trans-cinnamaldehyde (CIN: 98\%) was obtained from
Alfa Aesar (A Johnson Mathey Company, USA). Ultra High Temperature milk was purchased from the market milk (Seoul Dairy Co-op., Korea). Tryptic soya broth (TSB), tryptic soya agar (TSA), and MacConkey agar (MAC) were provided from Difco (Becton Dickinson and Company Sparks, MD, USA). Trichloroacetic acid was bought from DAEJUNG (DAE JUNG CHEMICAL \& METALS, Korea) and thiobarbituric acid was provided from VWR International (VWR Internaitonal Ltd., England).

\section{Cinnamon oil-milk (CM) manufacture}

CM $(0 \% \mathrm{CM}, 0.01 \% \mathrm{CM}, 0.05 \% \mathrm{CM}$, and $0.1 \% \mathrm{CM})$ was prepared in various formulations. $0,0.01,0.05$, and $0.1 \%(\mathrm{w} / \mathrm{v})$ CIN was added into the UHT milk. UHT milk added CIN was performed by homogenization using a high speed homogenizer (Ultra Turrax ${ }^{\circledR} \mathrm{T} 25$, IKA Labotechnik, Germany) at 11,000 rpm for $3 \mathrm{~min}$. The CM emulsions were high pressure homogenized (HPH) under 0 , 500 and 2,000 bar for 1 cycle by using the microfluidizer (Picomax ${ }^{\circledR}$ High Pressure Processor, MN400, Micronox, Korea). In every step of this process, the temperature of chamber was kept below $50^{\circ} \mathrm{C}$ through the use of an ice bath. The experiment was carried out to investigate the storage stability at $0,1,3,6$, and 10 storage d. During storage periods, $\mathrm{CM}$ was kept at $7^{\circ} \mathrm{C}$.

\section{Bacterial culture preparation}

Gram-negative bacteria E. coli ATCC 10536 supplied by America Type Culture Collection (Manassas, USA) was used in this study to evaluate the activity of CIN in vitro. The E. coli was cultured on tryptic soya agar (TSA) at $37^{\circ} \mathrm{C}$ for $24 \mathrm{~h}$ for active microorganisms, and stored at $-80^{\circ} \mathrm{C}$ in $50 \%$ sterile glycerol. Active cultures for experiments were prepared by transferring one loop full of cells from stock cultures to flask of tryptic soya broth (TSB), which were incubated at $37^{\circ} \mathrm{C}$ for $16-18 \mathrm{~h}$.

\section{Bacteria growth analysis}

For the inoculation of $\mathrm{CM}$ with bacteria, E. coli were inoculated into $5 \mathrm{~mL}$ of TSB and grown for $18 \mathrm{~h}$ at $37^{\circ} \mathrm{C}$ in incubator to inoculate $\mathrm{CM}$ with approximately $1 \times 10^{6}$ $\mathrm{CFU} / \mathrm{mL}$ of it. Amount of E. coli of the CM were analyzed between $10^{3}-10^{5} \mathrm{CFU} / \mathrm{mL}$ and the average $\log _{10}$ counts obtained on MAC. The stock $1 \mathrm{~mL}$ of $E$. coli culture was diluted in the $0.85 \% \mathrm{NaCl}$ solution $9 \mathrm{~mL} .0 .1$ $\mathrm{mL}$ of bacteria solution was then spread on the surface of MAC plates. The plates were incubated at $37^{\circ} \mathrm{C}$ for 24 to $48 \mathrm{~h}$. Detection of $E$. coli was based on enumeration of typical colonies according to the determination of colo- 
nies, and counting bacteria colony as the colony forming unit $(\mathrm{CFU} / \mathrm{mL})$.

\section{TBA value}

Lipid oxidation was also determined during storage. 1 $\mathrm{mL}$ of sample was mixed with $9 \mathrm{~mL}$ of $0.25 \mathrm{~N} \mathrm{HCl}$ solution containing $15 \%$ trichloroacetic acid (TCA) and $0.375 \%$ thiobarbituric acid (TBA). Each sample was heated to $95^{\circ} \mathrm{C}$ water bath for $15 \mathrm{~min}$ and was then cooled to room temperature. After cooling, they were centrifuged at $3,000 \mathrm{rpm}$ for $10 \mathrm{~min}$, and the absorbance of the clear supernatant liquid was measured by a UV-Visible spectrophotometer (OPTIZEN, Korea) at $535 \mathrm{~nm}$.

\section{Measurement of particle size}

Particle size of CM was determined by using a dynamic light scattering (DLS) instrument and the data was analyzed (Master sizer ${ }^{\circledR}$, Malvern Instruments, UK). It does this by measuring the intensity of light scattered as a laser beam passes through a dispersed particulate sample. This data is then analyzed to calculate the size of the particles that created the scattering pattern by using dispersion technology software supplied by manufacturer. Particle size was determined three times at room temperature, and the mean values were used.

\section{pH measurement}

$\mathrm{pH}$ of $\mathrm{CM}$ was determined during storage period by using a $\mathrm{pH}$ meter (Mettler Toledo $340^{\circledR}$, UK). The average three determinations taken at room temperature were used.

\section{Total color difference measurement}

Color was determined with a color reader (CR-10, Konica Minolta Sensing, Inc., Japan) which was calibrated using a white standard plate. The CIE $L^{*}, a^{*}$, and $b^{*}$ values were designated as indicators of lightness, redness, and yellowness, respectively. The objective of this transformation is the creation of a color space to aid in the numerical classification of color differences. CIE $L^{*} a^{*} b^{*}$ Scale is recommended by Commission International de l'Eclairage (CIE). The samples were determined post-preparation, and three measurements were taken from the surface of each sample.

\section{Interfacial tension measurement}

The interfacial tensions of CM samples were determined using a Tensiometer ${ }^{\circledR}$ (Sigma 703D KSV, USA). This method was used to measure the maximum weight of the liquid, which was lifted with a Du Nouy ring (ring radius $9.545 \mathrm{~mm}$, wire diameter $0.37 \mathrm{~mm}$ ) pulled out of the liquid's surface or interface. The ring was put above the surface, and the balance was zeroed. Then, the ring touched the surface and was pushed through it into the liquid, becoming wet, resulting in the formation of positive and negative forces being applied to the ring. The maximum force that was needed to pull the ring from the liquid was proportional to the surface tension of the liquid. All tests were carried out in triplicate.

\section{Statistical analysis}

The data were analyzed by ANOVA using the statistical program SAS (2008). Differences among the means were compared using Duncan's Multiple Range test, and the correlations between independent variables and measured values were calculated as Pearson's correlation coefficients.

\section{Results and Discussion}

\section{Effect of CIN or HPH on growth of $E$. coli during storage periods}

$\mathrm{CM}(0 \% \mathrm{CM}, 0.01 \% \mathrm{CM}, 0.05 \% \mathrm{CM}$, and $0.1 \% \mathrm{CM})$ was manufactured by the additon of various concentrations $[0$ to $0.1 \%(\mathrm{w} / \mathrm{v})]$ of $\mathrm{CIN}$, and different levels $(0,500$, and 2,000 bar) of $\mathrm{HPH}$, and was kept at $7^{\circ} \mathrm{C}$ for $10 \mathrm{~d}$. CM was inoculated with $E$. coli and its growth was observed to investigate the antibacterial activity of $0.05 \% \mathrm{CM}$ and $0.1 \% \mathrm{CM}$. CIN were effective in inhibiting the growth of $E$. coli during the storage period. E. coli were dramatically reduced in $0.1 \% \mathrm{CM}$ at $6 \mathrm{~d}$. They were slightly decreased from $6.3 \mathrm{Log} \mathrm{CFU} / \mathrm{mL}$ to $3.5 \mathrm{Log} \mathrm{CFU} / \mathrm{mL}$ in $0.05 \% \mathrm{CM}$ during the storage period $(10 \mathrm{~d})$. However, there was no antibacterial activity in either the $0 \% \mathrm{CM}$ or $0.01 \%$ CM. Furthermore, HPH processing had no effect on antibacterial activity (Fig. 1). In recent studies, 200, 250 and $300 \mathrm{MPa}$ was found to be effective in the inhibition of bacterial activation in bovine and soy milk (Cruz et al., 2007; Pereda et al., 2006; Thiebaud et al., 2003). A combination of $\mathrm{HPH}$ processing and the addition of essential oils was supposed to be more effective than single treatments of the milk (Evrendilek and Balasubramaniam, 2011). However, in this study, there was no clear effect on milk treated with HPH at 500 or 2,000 bar.

\section{Lipid oxidation}

TBA values were slightly increased from 0.145 to 0.191 in whole milk initially, upon treatment with CIN 

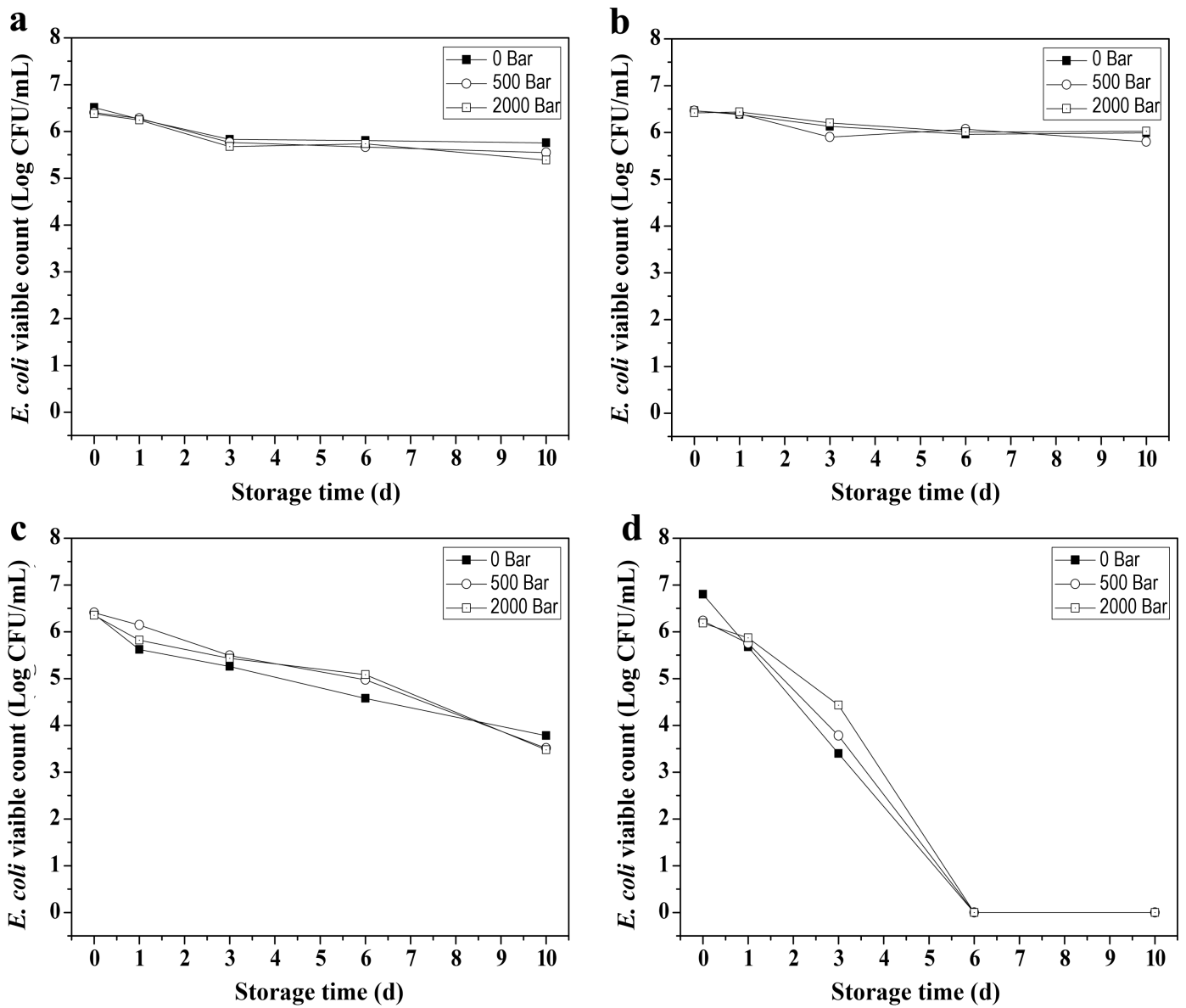

Fig. 1. Effect of CIN or high pressure homogenization to $\boldsymbol{E}$. coli growth in $\mathbf{C M}$ during storage periods. CIN concentration: a, $0 \%$; b, $0.01 \%$; c, $0.05 \%$;, $0.1 \%(\mathrm{w} / \mathrm{v})$

(Fig. 2). All milk samples showed similar trends of lipid oxidation. Among the all $\mathrm{CM}, 0.05 \% \mathrm{CM}$ and $0.1 \% \mathrm{CM}$ treated 500 bar HPH had a slightly lower TBA value of 0.159 and at the end of the storage period, $0.1 \% \mathrm{CM}$ treated 2,000 bar HPH had the lowest TBA value of 0.161 . The addition of CIN was more effective in increasing the TBA value than HPH treatment. HPH milk had higher TBA values than raw milk, because HPH processing generated heat, resulting in temperatures of up to $50^{\circ} \mathrm{C}$, which is near the denaturation temperature of milk proteins. Moreover, HPH increased the surface area of milk, with the result that HPH treated milk was more easily oxidized than raw milk. However, over $0.1 \%(\mathrm{w} / \mathrm{v})$ CIN was effective in inhibiting lipid oxidation of milk. As Fig. 2 shows, specially, the variation was big end of storage periods. It was expected that TBA values were influenced by flocculation of milk droplet during storage periods. Flocculation of milk droplet generated, but it might did not affect particle size appreciably. However, oxidation could be occurred by exposure of CIN which was broken by excessive flocculation of cinnamon oil milk's droplets.

\section{Particle size}

The Particle size of $\mathrm{CM}$ was measured by $\mathrm{D}_{4,3}$ of size parameter (Table 1) which gave average size of the disperse phase of milk diluted emulsions. In $\mathrm{D}_{4,3}$ parameter measurement, the particle size of milk was determined to range from $0.40 \mu \mathrm{m}$ to $8.92 \mu \mathrm{m}$ during storage periods. Particle size of CM was decreased with higher pressure levels or increasing CIN concentration. The particle size of CM was increased significantly as storage periods progressed for all CM $(p<0.05)$. In Cruz et al. (2007) study, the particle size of raw soy milk was $0.55 \mu \mathrm{m}$, and that of ultra high pressure $(200 \mathrm{MPa})$ treated soy milk was 0.14 $\mu \mathrm{m}$ according to in $\mathrm{D}_{4,3}$ size determinations. It was supposed that treatment with high pressure was effective in decreasing the particle size of bovine or soy milk. In this study, HPH was initially effective in decreasing the size of milk droplets, but milk droplets became larger over time. 

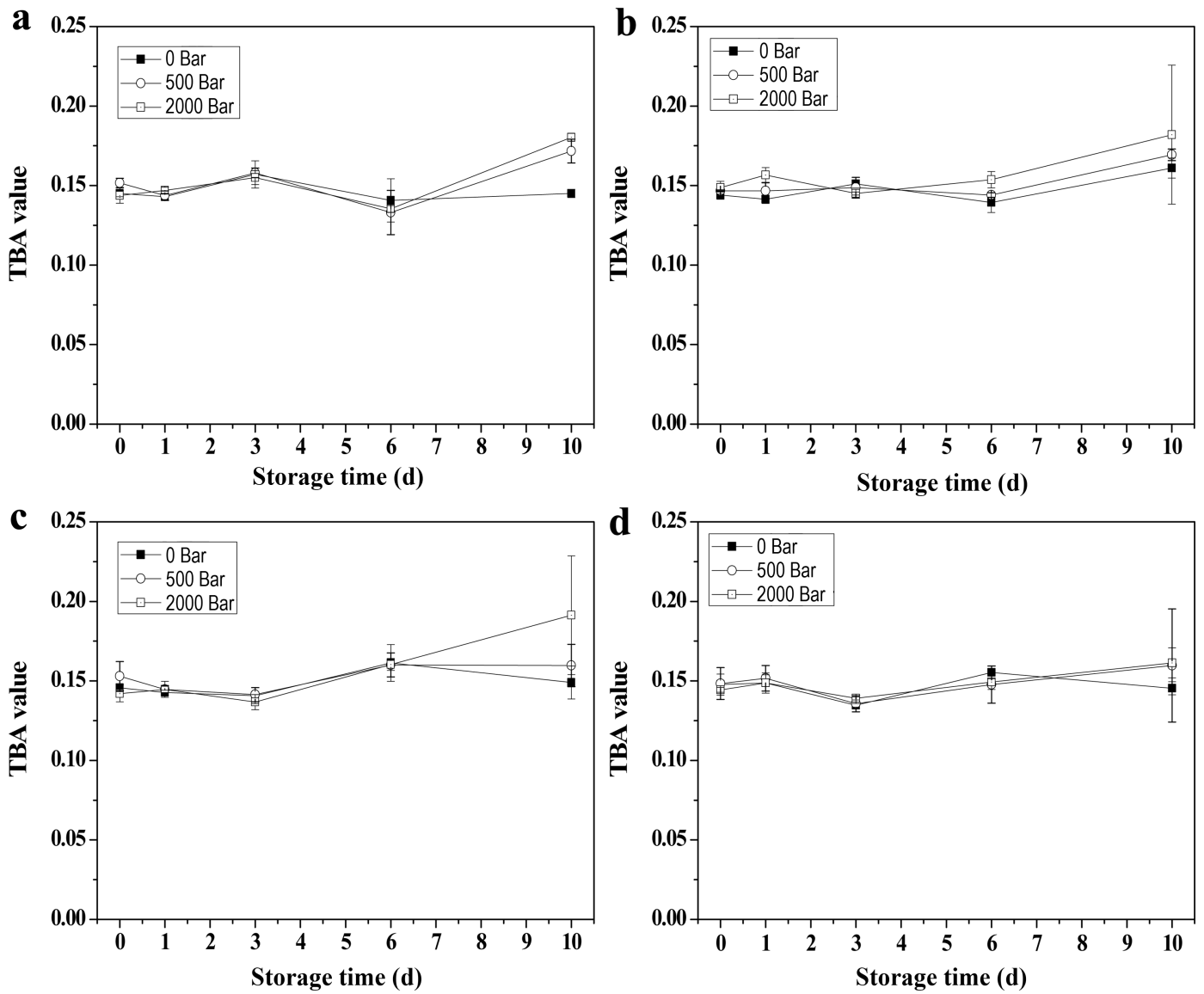

Fig. 2. Effect of CIN or high pressure homogenization to lipid oxidation in CM during storage periods. CIN concentration: a, $0 \%$; b, $0.01 \% ; c, 0.05 \%$;, $0.1 \%(w / v)$

Table 1. Particle size of $\mathrm{CM}$ during storage periods in $\mathrm{D}_{4,3}$ size parameter

\begin{tabular}{|c|c|c|c|c|c|c|}
\hline \multirow{2}{*}{$\begin{array}{l}\text { Pressure } \\
\text { (bar) }\end{array}$} & \multirow{2}{*}{$\begin{array}{c}\text { CIN } \\
(\%, w / v)\end{array}$} & \multicolumn{5}{|c|}{ Storage time $(\mathrm{d})$} \\
\hline & & 0 & 1 & 3 & 6 & 10 \\
\hline \multirow{4}{*}{0} & 0 & $0.507 \pm 0.001^{1) \mathrm{bB}}$ & $0.517 \pm 0.001^{\mathrm{aA}}$ & $0.500 \pm 0.000^{\mathrm{bB}}$ & $0.523 \pm 0.001^{\mathrm{aA}}$ & $0.453 \pm 0.001^{\mathrm{cF}}$ \\
\hline & 0.01 & $0.510 \pm 0.000^{\mathrm{bAB}}$ & $0.500 \pm 0.000^{\mathrm{bC}}$ & $0.510 \pm 0.000^{\mathrm{bA}}$ & $0.510 \pm 0.000^{\mathrm{bB}}$ & $5.620 \pm 0.195^{\mathrm{aC}}$ \\
\hline & 0.05 & $0.500 \pm 0.000^{\mathrm{bC}}$ & $0.513 \pm 0.006^{\mathrm{aAB}}$ & $0.500 \pm 0.000^{\mathrm{bB}}$ & $0.510 \pm 0.000^{\mathrm{aB}}$ & $0.510 \pm 0.000^{\mathrm{aE}}$ \\
\hline & 0.1 & $0.500 \pm 0.000^{\mathrm{bC}}$ & $0.490 \pm 0.000^{\mathrm{cD}}$ & $0.510 \pm 0.000^{\mathrm{aA}}$ & $0.510 \pm 0.000^{\mathrm{aB}}$ & $0.510 \pm 0.000^{\mathrm{aE}}$ \\
\hline \multirow{4}{*}{500} & 0 & $0.513 \pm 0.006^{\mathrm{bA}}$ & $0.500 \pm 0.000^{\mathrm{bC}}$ & $0.493 \pm 0.006^{\mathrm{bC}}$ & $0.527 \pm 0.006^{\mathrm{bA}}$ & $5.647 \pm 0.311^{\mathrm{aC}}$ \\
\hline & 0.01 & $0.510 \pm 0.000^{\mathrm{bAB}}$ & $0.510 \pm 0.006^{\mathrm{bAB}}$ & $0.49 \pm 0.0006^{\mathrm{bC}}$ & $0.490 \pm 0.006^{\mathrm{bC}}$ & $0.880 \pm 0.025^{\mathrm{aD}}$ \\
\hline & 0.05 & $0.490 \pm 0.000^{\mathrm{bD}}$ & $0.510 \pm 0.000^{\mathrm{bB}}$ & $0.490 \pm 0.000^{\mathrm{bC}}$ & $0.493 \pm 0.006^{\mathrm{bC}}$ & $8.923 \pm 0.415^{\mathrm{aA}}$ \\
\hline & 0.1 & $0.493 \pm 0.006^{\mathrm{aD}}$ & $0.500 \pm 0.000^{\mathrm{aC}}$ & $0.500 \pm 0.000^{\mathrm{aB}}$ & $0.497 \pm 0.000^{\mathrm{aC}}$ & $7.720 \pm 0.139^{\mathrm{aB}}$ \\
\hline \multirow{4}{*}{2,000} & 0 & $0.400 \pm 0.000^{\mathrm{eG}}$ & $0.410 \pm 0.000^{\mathrm{bG}}$ & $0.410 \pm 0.000^{\mathrm{bF}}$ & $0.420 \pm 0.000^{\mathrm{bE}}$ & $5.650 \pm 0.231^{\mathrm{aC}}$ \\
\hline & 0.01 & $0.400 \pm 0.000^{\mathrm{eG}}$ & $0.400 \pm 0.000^{\mathrm{cH}}$ & $0.420 \pm 0.000^{\mathrm{bE}}$ & $0.420 \pm 0.000^{\mathrm{bE}}$ & $0.430 \pm 0.000^{\mathrm{aE}}$ \\
\hline & 0.05 & $0.450 \pm 0.000^{\mathrm{eE}}$ & $0.450 \pm 0.000^{\mathrm{bE}}$ & $0.450 \pm 0.000^{\mathrm{bD}}$ & $0.453 \pm 0.006^{\mathrm{bD}}$ & $0.523 \pm 0.006^{\mathrm{aE}}$ \\
\hline & 0.1 & $0.420 \pm 0.000^{\mathrm{eF}}$ & $0.440 \pm 0.000^{\mathrm{bF}}$ & $0.420 \pm 0.000^{\mathrm{cE}}$ & $0.457 \pm 0.006^{\mathrm{aD}}$ & $0.440 \pm 0.000^{\mathrm{bE}}$ \\
\hline
\end{tabular}

\footnotetext{
${ }^{1)}$ Average $\pm \mathrm{SD}(\mathrm{n}=3)$.

${ }^{\mathrm{a}-\mathrm{e}}$ Means that different superscript within the same row are significantly different $(p<0.05)$.

${ }^{\text {A-F }}$ Means with different superscript within same column are significantly different $(p<0.05)$.
}

\section{pH measurement}

The $\mathrm{pH}$ of $\mathrm{CM}$ was measured from 6.40 to 6.61 during storage periods (Table 2). The $\mathrm{pH}$ of samples did not changed over the storage period, and there was no signif- icant difference according to the level of pressure applied (Table $2, p>0.05$ ). $\mathrm{pH}$ was increased slightly with increasing CIN concentration, but there was no significant difference $(p>0.05)$. This level is similar to that of fresh milk 
Table 2. Change of pH value during storage periods

\begin{tabular}{ccccccc}
\hline \hline \multirow{2}{*}{$\begin{array}{c}\text { Pressure } \\
(\text { bar })\end{array}$} & $\begin{array}{c}\mathrm{CIN} \\
(\%, \mathrm{w} / \mathrm{v})\end{array}$ & \multicolumn{5}{c}{ Storage time (d) } \\
\cline { 3 - 7 } & 0 & $6.47 \pm 0.02^{\mathrm{l}) \mathrm{cF}}$ & $6.50 \pm 0.01^{\mathrm{bF}}$ & $6.60 \pm 0.02^{\mathrm{aB}}$ & $6.61 \pm 0.01^{\mathrm{aAB}}$ & $6.61 \pm 0.02^{\mathrm{aAB}}$ \\
& 0.01 & $6.63 \pm 0.01^{\mathrm{aA}}$ & $6.51 \pm 0.01^{\mathrm{cF}}$ & $6.61 \pm 0.01^{\mathrm{abA}}$ & $6.61 \pm 0.01^{\mathrm{bAB}}$ & $6.48 \pm 0.03^{\mathrm{dD}}$ \\
0 & 0.05 & $6.63 \pm 0.01^{\mathrm{aAB}}$ & $6.63 \pm 0.01^{\mathrm{aC}}$ & $6.61 \pm 0.01^{\mathrm{bAB}}$ & $6.59 \pm 0.01^{\mathrm{cBC}}$ & $6.59 \pm 0.01^{\mathrm{cB}}$ \\
& 0.1 & $6.63 \pm 0.01^{\mathrm{aA}}$ & $6.63 \pm 0.01^{\mathrm{aC}}$ & $6.60 \pm 0.01^{\mathrm{bAB}}$ & $6.60 \pm 0.01^{\mathrm{bABC}}$ & $6.62 \pm 0.01^{\mathrm{aA}}$ \\
\hline & 0 & $6.49 \pm 0.02^{\mathrm{cE}}$ & $6.65 \pm 0.01^{\mathrm{aB}}$ & $6.60 \pm 0.01^{\mathrm{bB}}$ & $6.48 \pm 0.02^{\mathrm{cE}}$ & $6.45 \pm 0.01^{\mathrm{dE}}$ \\
& 0.01 & $6.63 \pm 0.01^{\mathrm{bA}}$ & $6.65 \pm 0.01^{\mathrm{aAB}}$ & $6.61 \pm 0.01^{\mathrm{cAB}}$ & $6.60 \pm 0.01^{\mathrm{cABC}}$ & $6.48 \pm 0.01^{\mathrm{dD}}$ \\
& 0.05 & $6.61 \pm 0.01^{\mathrm{aCD}}$ & $6.60 \pm 0.01^{\mathrm{aE}}$ & $6.60 \pm 0.01^{\mathrm{aB}}$ & $6.57 \pm 0.01^{\mathrm{bD}}$ & $6.40 \pm 0.01^{\mathrm{cF}}$ \\
& 0.1 & $6.61 \pm 0.01^{\mathrm{bCD}}$ & $6.63 \pm 0.00^{\mathrm{aC}}$ & $6.61 \pm 0.01^{\mathrm{bA}}$ & $6.62 \pm 0.01^{\mathrm{abA}}$ & $6.59 \pm 0.01^{\mathrm{cB}}$ \\
\hline \multirow{3}{*}{500} & 0 & $6.50 \pm 0.01^{\mathrm{cE}}$ & $6.66 \pm 0.01^{\mathrm{aA}}$ & $6.58 \pm 0.01^{\mathrm{bC}}$ & $6.59 \pm 0.01^{\mathrm{bC}}$ & $6.46 \pm 0.01^{\mathrm{dE}}$ \\
& 0.01 & $6.60 \pm 0.01^{\mathrm{dD}}$ & $6.63 \pm 0.01^{\mathrm{aC}}$ & $6.60 \pm 0.01^{\mathrm{cAB}}$ & $6.62 \pm 0.01^{\mathrm{bA}}$ & $6.60 \pm 1.09^{\mathrm{dcAB}}$ \\
& 0.05 & $6.61 \pm 0.01^{\mathrm{abCD}}$ & $6.62 \pm 0.01^{\mathrm{aD}}$ & $6.60 \pm 1.09^{\mathrm{bAB}}$ & $6.60 \pm 0.01^{\mathrm{bABC}}$ & $6.51 \pm 0.01^{\mathrm{cC}}$ \\
& 0.1 & $6.61 \pm 0.01^{\mathrm{abBC}}$ & $6.62 \pm 0.01^{\mathrm{aCD}}$ & $6.61 \pm 0.01^{\mathrm{aA}}$ & $6.60 \pm 0.01^{\mathrm{bcABC}}$ & $6.60 \pm 0.01^{\mathrm{cAB}}$ \\
\hline
\end{tabular}

${ }^{1)}$ Average \pm SD $(n=3)$.

${ }^{\mathrm{a}-\mathrm{c}}$ Means that different superscript within the same row are significantly different $(p<0.05)$.

${ }^{A-E}$ Means with different superscript within same column are significantly different $(p<0.05)$.

Table 3. Total color difference of CM as CIN concentration or high pressure level during storage periods

\begin{tabular}{|c|c|c|c|c|c|c|}
\hline \multicolumn{2}{|c|}{ Treatments } & \multicolumn{5}{|c|}{ Storage time $(\mathrm{d})$} \\
\hline $\operatorname{CIN}(\%, w / v)$ & Pressure (bar) & 0 & 1 & 3 & 6 & 10 \\
\hline \multirow{3}{*}{0} & 0 & $51.31 \pm 0.26$ & $51.48 \pm 0.49$ & $51.46 \pm 0.09$ & $51.45 \pm 0.11$ & $51.71 \pm 0.11$ \\
\hline & 500 & $51.32 \pm 0.31$ & $51.71 \pm 0.14$ & $51.52 \pm 0.28$ & $51.61 \pm 0.05$ & $51.09 \pm 0.06$ \\
\hline & 2000 & $50.99 \pm 0.22$ & $51.77 \pm 0.11$ & $51.51 \pm 0.09$ & $51.03 \pm 0.16$ & $50.70 \pm 0.05$ \\
\hline \multirow{3}{*}{0.01} & 0 & $51.87 \pm 0.18$ & $51.71 \pm 0.18$ & $51.41 \pm 0.22$ & $51.74 \pm 0.06$ & $50.81 \pm 0.01$ \\
\hline & 500 & $51.15 \pm 0.29$ & $51.73 \pm 0.14$ & $51.74 \pm 0.05$ & $51.75 \pm 0.05$ & $51.28 \pm 0.05$ \\
\hline & 2000 & $50.95 \pm 0.63$ & $51.32 \pm 0.10$ & $51.42 \pm 0.24$ & $51.59 \pm 0.11$ & $50.92 \pm 0.05$ \\
\hline \multirow{3}{*}{0.05} & 0 & $51.97 \pm 0.42$ & $50.33 \pm 0.14$ & $51.01 \pm 0.05$ & $51.74 \pm 0.13$ & $51.66 \pm 0.04$ \\
\hline & 500 & $52.02 \pm 0.35$ & $50.87 \pm 0.64$ & $51.39 \pm 0.09$ & $51.47 \pm 0.05$ & $51.48 \pm 0.06$ \\
\hline & 2000 & $51.77 \pm 0.20$ & $50.75 \pm 0.63$ & $51.26 \pm 0.19$ & $51.64 \pm 0.04$ & $51.14 \pm 0.05$ \\
\hline \multirow{3}{*}{0.1} & 0 & $51.45 \pm 0.18$ & $50.85 \pm 0.10$ & $51.37 \pm 0.18$ & $51.25 \pm 0.11$ & $50.81 \pm 0.06$ \\
\hline & 500 & $52.26 \pm 0.07$ & $50.48 \pm 0.11$ & $51.42 \pm 0.06$ & $51.88 \pm 0.11$ & $51.10 \pm 0.10$ \\
\hline & 2000 & $52.26 \pm 0.11$ & $50.82 \pm 0.17$ & $51.53 \pm 0.11$ & $51.55 \pm 0.05$ & $51.02 \pm 0.01$ \\
\hline
\end{tabular}

(pH 6.6-6.8) (Kim, 2007). In Kim et al. (2007) study, it was not influenced significantly by high pressure $(200$ MPa) with low temperature treatment. They suggested that high pressure processing was not responsible for the pH change. Hayes et al. (2005) also prepared milk treated high pressure at 1,500 bar, 2,000 and 2,500 and then milk were kept at $4^{\circ} \mathrm{C}$ for $14 \mathrm{~d}$. The $\mathrm{pH}$ of milk treated at 1,500 bar was decreased from 6.65 to 6.0 ; however, there was no decrease in the $\mathrm{pH}$ of milk treated at 2,000 or 2,500 bar. It was suggested that high pressure treatment did not affect $\mathrm{pH}$ of milk according several researches including this study.

\section{Total color difference}

Total color ranged from 50.33 to 52.26 (Table 3). Total color difference of raw milk was slightly increased pres- sure increased. However, the color of $\mathrm{CM}$ samples varied irregularly during the storage period. And the reason that $0.1 \% \mathrm{CM}$ had a rather higher value than others was the original color of CIN.

\section{Surface tension}

The range of surface tension was from 43.05 to 50.06 $\mathrm{mN} / \mathrm{m}$ during the storage period (Fig. 3). $\mathrm{CM}$ treated HPH was higher than non-treated CM. Interestingly, surface tension of $0 \% \mathrm{CM}$ treated 2000 bar was remarkably increased from $3 \mathrm{~d}$ of the storage period up to around $50.06 \mathrm{mN} / \mathrm{m}$. HPH processing slightly affected the interfacial tension of CM. Some researchers have reported modification of protein denaturation by high hydrostatic pressure. When pressure is released from the emulsion system the unfolded protein could partly return to its orig- 

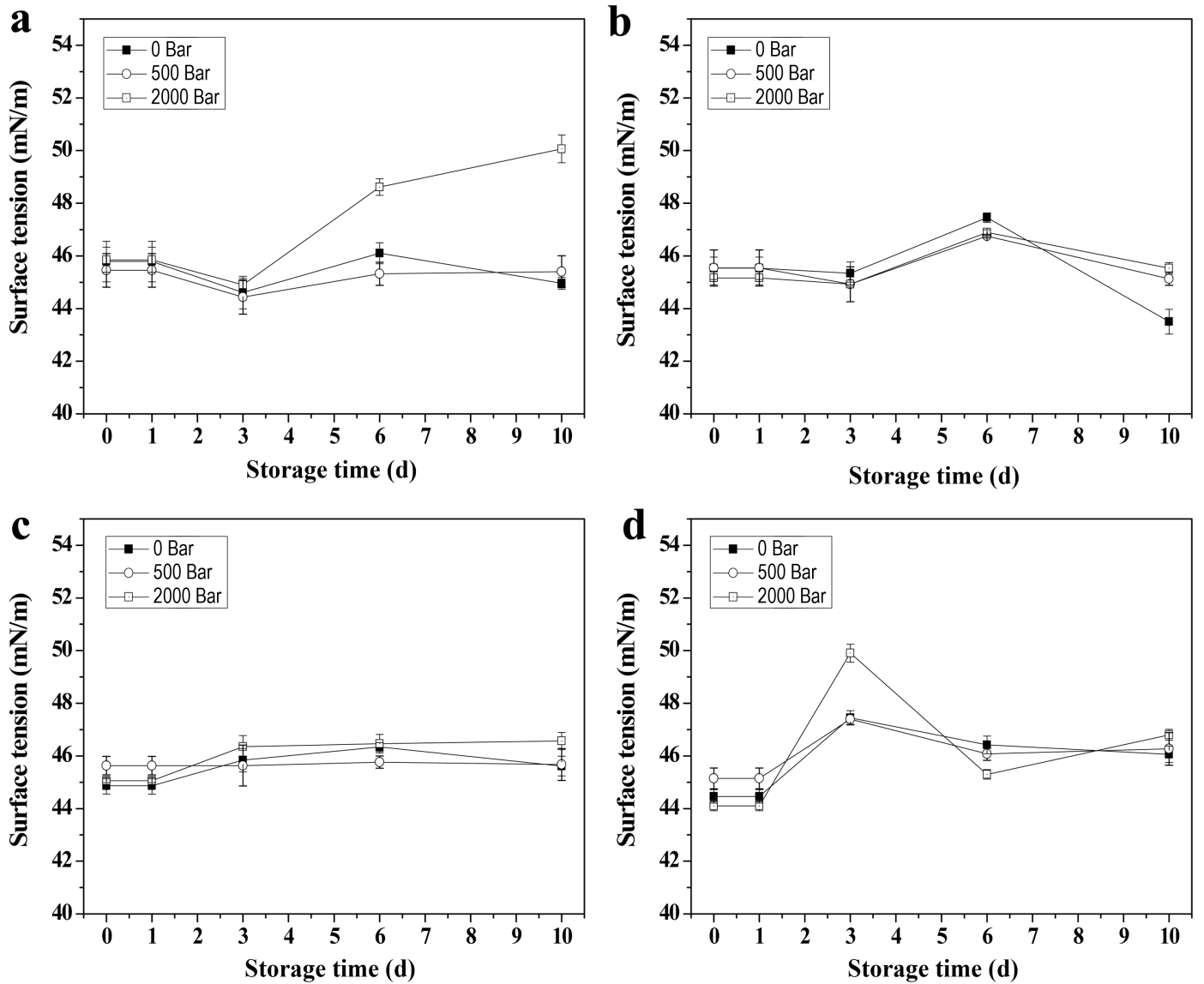

Fig. 3. Effect of CIN or high pressure homogenization to surface tension in CM during storage periods. CIN concentration: a, $0 \%$; b, $0.01 \%$; c, $0.05 \%$; d, $0.1 \%$ (w/v)

inal protein structure, noted as reversible protein denaturation. Furthermore, the unfolded protein can be adsorbed onto the surface of the oil droplets and reform, to adhere more strongly by pressurization (Iordache and Jelen, 2003; Surassmo, 2011).

\section{Conclusion}

This study was carried out in order to investigate the effects of trans-cinnamaldehyde and HPH treatment on the physio-chemical and microbial properties of milk. The addition of over $0.05 \%(\mathrm{w} / \mathrm{v})$ trans-cinnamaldehyde had antimicrobial activity in milk, and $0.1 \%(\mathrm{w} / \mathrm{v})$ of trans-cinnamaldehyde had a high efficacy in decreasing the number of $E$. coli CFUs in the milk. Moreover, it was also effective in inhibiting lipid oxidation by TBA value. It was determined that the addition of trans-cinnamaldehyde could improve the chemical and microbial stability of milk during storage. Although HPH treatment was not effective on antimicrobial activity in this study as expected, $\mathrm{HPH}$ did decrease the particle size of $\mathrm{CM}$, and furthermore, the reduced size of particles of $\mathrm{CM}$ increased the rate of lipid oxidation, due to the increase in surface area. It was suggested that the addition of transcinnamaldehyde had more influence on the stability of milk than high energy physical processing.

\section{Acknowledgement}

This paper was supported by Konkuk University in 2010.

\section{References}

1. Amrita, V., Sonal, D., and Shalini, R. (2009) Antibacterial effect of herbs and spices extract on Escherichia coli. eJBio 5, 40-44.

2. Bouaouina, H., Desrumaux, A., Loisel, C., and Legrand, J. (2006) Functional properties of whey proteins as affected by dynamic high-pressure treatment. Int. Dairy J. 16, 275-284.

3. Burt, S. (2004) Essential oils: their antibacterial properties and potential applications in foods - a review. Int. J. Food Microbiol. 94, 223-253. 
4. Cevallos, P. A. P., Buera, M. P., Elizalde, B. E., and Desrumaux, A. (2010) Encapsulation of cinnamon and thyme essential oils components (cinnamaldehyde and thymol) in beta-cyclodextrin: Effect of interactions with water on complex stability. J Food Eng. 99, 70-75.

5. Chun, J. Y. (2012) Physical properties of molecular inclusion complexes of essential oils with $\beta$-cyclodextrin and formation of multiple-layered liposomes by electrostatic deposition of biopolymer. Ph.D. thesis, Konkuk Univ., Seoul, Korea.

6. Ciron, C. I. E., Gee, V. L., Kelly, A. L., and Auty, M. A. E. (2010) Comparison of the effects of high-pressure microfluidization and conventional homogenization of milk on particle size, water retention and texture of non-fat and low-fat yoghurts. Int. Dairy J. 20, 314-320.

7. Cook, E. J. and Lagace, A. P. (1985) Apparatus for forming emulsions, U.S. Patent 4,533,254. US.

8. Cruz, N., Capellas, M., Hernández, M., Trujillo, A. J., Guamis, B., and Ferragut, V. (2007) Ultra high pressure homogenization of soymilk: Microbiological, physicochemical and microstructural characteristics. Food Res. Int. 40, 725-732.

9. Evrendilek, G. A. and Balasubramaniam, V. M. (2011) Inactivation of Listeria monocytogenes and Listeria innocua in yogurt drink applying combination of high pressure processing and mint essential oils. Food Control 22, 1435-1441.

10. Goñi, P., López, P., Sánchez, C., Gómez-Lus, R., Becerril, R., and Nerín, C. (2009). Antimicrobial activity in the vapour phase of a combination of cinnamon and clove essential oils. Food Chem. 116, 982-989.

11. Hayes, M. G., Fox, P. F., and Kelly, A. L. (2005) Potential applications of high pressure homogenisation in processing of liquid milk. J. Dairy Res. 72, 25-33.

12. Hossain, M. B., Brunton, N. P., Barry-Ryan, C., MartinDiana, A. B., and Wilkinson, M. (2008) Antioxidant activity of spice extracts and phenolics in comparison to synthetic antioxidant. Rasayan J. Chem. 1, 751-756.

13. Hossain, M. B., Patras, A., Barry-Ryan, C., Martin-Diana, A. B., and Brunton, N. P. (2011) Application of principal component and hierarchical cluster analysis to classify different spices based on in vitro antioxidant activity and individual polyphenolic antioxidant compounds. J. Functional Foods 3, 179-189.

14. Iordache, M. and Jelen, P. (2003) High pressure microfluidization treatment of heat denatured whey proteins for improved functionality. Innovat. Food Sci. Emerg. Tech. 4, 367-376.

15. Kim, H. Y. (2007) The effect of high pressure low temperature on physicochemical properties in milk. MS thesis, Sejong
Univ., Seoul, Korea.

16. McClements, D. J. and Qian, C. (2011) Formation of nanoemulsions stabilized by model food-grade emulsifiers using high-pressure homogenization: Factors affecting particle size. Food Hydrocolloid. 25, 1000-1008.

17. Paquin, P. (1999) Technological properties of high pressure homogenizers: the effect of fat globules, milk proteins, and polysaccharides. Int. Dairy J. 9, 329-335.

18. Pereda, J., Ferragut, V., Guamis, B., and Trujillo, A. J. (2006) Effect of ultra high-pressure homogenisation on naturaloccurring micro-organisms in bovine milk. Milchwissenschaft 61, 245-248.

19. Rahman, A. K., Bajpai, V. D. T., and Kang, S. C. (2011) Antibacterial and antioxidant activities of the essential oil and methanol extracts of Bidens frondosa Linn. Int. J. Food Sci. Technol. 46, 1238-1244.

20. SAS (2008) SAS/STAT Software for PC. Release 9.2, SAS Institute Inc., Cary, NC, USA.

21. Smiddy, M. A., Martin, J. E., Huppertz, T., and Kelly, A. L. (2007) Microbial shelf-life of high-pressure-homogenised milk. Int. Dairy J. 17, 29-32.

22. Surassmo, S. (2011) Development of nanocapsulation system incorporated with biopolymer for enhancement of functional properties of capsicum oleoresin and trans-cinnamaldehyde. Ph.D. thesis, Konkuk Univ., Seoul, Korea.

23. Thiebaud, M., Dumay, E., Picart, L., Guiraud, J. P., and Cheftel, J. C. (2003) High-pressure homogenisation of raw bovine milk. Effects on fat globule size distribution and microbial inactivation. Int. Dairy J. 13, 427-439.

24. Van Hekken, D. L., Tunick, M. H., Malin, E. L., and Holsinger, V. H. (2007) Rheology and melt characterization of low-fat and full fat Mozzarella cheese made from microfluidized milk. LWT-Food Sci. Technol. 40, 89-98.

25. Vassila, E., Badeka, A., Kondyli, E., Savvaidis, I., and Kontominas, M. G. (2002) Chemical and microbiological changes in fluid milk as affected by packaging conditions. Int. Dairy J. 12, 715-722.

26. Wormbs, G., Larsson, A., Alm, J., Tunklint-Aspelin, C., Strinning, O., Danielsson, E., and Larsson, H. (2004) The use of design of experiment and sensory analysis as tools for the evaluation of production methods for milk. Chemometr. Intell. Lab. Syst. 73, 67-71.

27. Yossa, N., Patel, J., Miller, P., and Lo, Y. M. (2010) Antimicrobial activity of essential oils against Escherichia coli O157:H7 in organic soil. Food Control 21, 1458-1465.

(Received 2012.8.21/Revised 2012.11.14/Accepted 2012.12.7) 